2017-07-18

\title{
Writing to it: creative engagements with writing practice in and with the not yet known in today's academy
}

Wyatt, J

http://hdl.handle.net/10026.1/10054

\subsection{0/09518398.2017.1349957}

International Journal of Qualitative Studies in Education Informa UK Limited

All content in PEARL is protected by copyright law. Author manuscripts are made available in accordance with publisher policies. Please cite only the published version using the details provided on the item record or document. In the absence of an open licence (e.g. Creative Commons), permissions for further reuse of content should be sought from the publisher or author. 


\section{Writing to it: creative engagements with writing practice in and with the not yet known in today's academy}

We have developed an approach to collaborative-writing-as-inquiry that we sometimes refer to as 'between the twos' (e.g. Author $2 \&$ Author 1, 2009). We have, over the years, sensed they/we were part of the multiplicity of an incessant becoming, becoming something other than what we/they were. In this we sense the emergence of powers to affect and be affected in our collaborative writing practices and to begin to animate a response to Spinoza's fundamental inquiry into what bodies can do.

In working with a 'logic of sense' (Deleuze, 2004) we are working continually to bring concepts to life in event and to transversally give them creative life through extending Richardson's (Richardson and St. Pierre, 2005) practice of writing as method of inquiry through the use of collaborative modalities of practice. Increasingly, we are coming to understand that the only way to continue in this sense-making and affecting is to 'write to it'. Issues, queries and question arise - in our lives and in our writing - and we say to the other, "let's write to it". Whatever the query or the problem, it is this inducement - 'write to it' that leads to new experimentations and the sensing of the indeterminate rhythms and refrains of the multiple that activates our practice. In this, through making what Barad refers to as “agential cuts" (2007, p. 175) we work intra-actively with productive desiring within and against the traditional representations of research and pedagogic practice in universities.

We are with Massumi when he says "(t)o affect and be affected is to be open to the world, to be active in it and to be patient for its return activity" (2015, p. ix) and so our work offers challenge to the controlling performatives of practice that characterise much of what happens in present day institutions of higher education. We take the view that within the practice of 'writing to it' we are transversally engaging and actively producing, through the animation of 
a philosophy of the event, what Deleuze and Guattari refer to as 'minor literatures' (Deleuze \& Guattari, 1986):

"the notion of linguistic action, whereby we write to and as experiment, where we take on the dominating forces of the 'major literature' that works to produce the canon and the normative force of the privileged practice style and where the living, embodied, performative action of our words and sentences challenges and takes on the coercive and colonising effects of the regulating logic, the traditional grammar and stylistic preferences of the dominant majoritarian form.” (Guttorm et al., 2012, p. 395)

In offering opportunities for bringing non-totalising modes of sensing to life within Deleuze and Guattari's experimental and creative originations, and in the multiplicity and the vibrant potentialities of always becoming, we make claims for innovative, creatively-productive writing practices that might bring new life to research, inquiry and pedagogic practice in the university of the future (see also Sellers \& Gough, 2010).

With the intention to bring such claims to life, to animate them rather then only write about them, the paper borrows from Author 1 et al. (2010) and Gough \& Gough (2016) in taking dialogic play script form: exchanges between the two of us, often written as we travel, the movement an inducement, a prompt; and exchanges between ourselves and those with, to and from whose work we speak. Between us all we see where writing takes us.

\section{Immanent imperative}

J: Writing to it. Present participle, followed by preposition, succeeded by impersonal pronoun. Writing. To. It. 
'Writing to it': as if writing had direction. As if it were purposeful. Intentional. Instrumental. A goal in mind.

Like a harsh teacher bellowing instructions to cowed children: 'Enough messing about. You heard what I said - now put down the guinea pig, get out your pens and start writing to it. You horrible lot.'

That's how teachers in my school spoke to us. Though I'm not sure what the guinea pig is doing there.

Or like the words of a sergeant-major on the parade ground: 'Right! Left! Right! Left! Writing to it!' More of an imaginative stretch, but it possesses a sense of writing as commanded and required.

(I'm on a train north from Manchester on a crowded Friday afternoon. The seats are narrow and privacy is difficult to maintain. I'm at a table, typing. The young woman next to me, whom I haven't yet spoken to, after 90 minutes, has taken a break from her phone to look around. She seems to be looking towards my screen. I can see that her head is turned this way, but I don't want to turn and check. That would seem too wary and I wouldn't want to put her on the defensive. She's reading this text now, I sense. If she is, I want to ask her what she's making of this, whether she'd like me to give her some background. Maybe I could give her a paper to read on this too-slow journey from Carlisle to Lockerbie. 'Here, take a look at Author 2 and Author 1, 2013, on assemblage/ethnography. It'll give you the idea.' I suspect she would refuse the offer.

And now I'm thinking if she is reading then she will realise that I'm writing about her. Now. Which will seem weird. Creepy, even. Perhaps I should stop.) 
The instrumental, line-of-command connotations of 'writing to it' that I've suggested, with their arguable associations with traditional academic writing's commitment to 'transparency' and 'communication', are of course not at all the sense that we intend to convey, nor is it the way that over the years we have used it. In fact, I'm tempted to say it is the opposite of that and anathema to us. When we use the phrase 'write to it' we mean exploratory, inquiring, open, hesitant, writing. Writing as flow.' Writing to it' is, as Karen Lee writes:

K: “a gesture of longing” (Lee, 2005, p.935).

$\mathrm{J}$ : Writing that takes us over, writing that becomes.

However, I hesitate in my recoiling. It always pays to be suspicious of binaries. There may be something in the bullying teacher and the barking sergeant-major. Something in their instructions. Something, despite their abhorrence, in the commands issued by those creations that might be offering us something here, something we might find ourselves taking up in this paper. If so it is perhaps this: the sense of compulsion in 'writing to it'. Not an imposed, authoritarian, punitive compulsion, but a compulsion we have found arising in us. A way of coming to understand writing not as something we 'do' but as something that 'does' us. A practice we have found ourselves doing. An immanent imperative. Which does not mean that it happens without effort nor that it is unproblematic. It does not happen by magic. Or not by magic alone, anyway.

Writing takes it out of us; and takes us out of ourselves; and out of it. We get out of it by writing. We have to.

\section{Recoiling}


$\mathrm{K}$ : Yes, I feel something in your recoil. I have never fired a gun but I have a sense of how it might feel when the trigger is pulled and the butt of the rifle thumps into your shoulder hollow forcing you to step back. The suspicion of binaries that you refer to works something like that: we have grown up with them, their discursive effect is insidious, we have grown to be reflexive and wisely warn against them and still we receive an impact, a jolt, when we find ourselves using them again.

So I like the sense in which you carefully step back in your writing to allow space for the imbrication of the different conceptualisations of 'writing to it' to be possible. It is that space, as a territorialisation, that opens up for me; it is the little plot of land that offers immediate spatio-temporal emergence. In one sense this resonates with the facilitative pedagogical practice of 'intervention' (see Heron, 2001) in which different practice styles are used to facilitate the pedagogically inclined process. Within the humanistic proclivities of such practices, where interactive strategies - qua intentional, directed action between the ontologically separate, the one who does and the other who is done to - are employed to achieve certain learning goals or therapeutic ends, sense is made whereby a 'prescriptive' intervention, say, is categorised as being qualitatively different from a 'cathartic' intervention or a 'catalytic' one. According to such principles, the facilitator or the therapist will act differently as a means of bringing about change in the student or the client. As you seem to suggest in your imbrication of these different possible approaches to 'prescription', in what you describe as an 'immanent imperative', where 'writing to it' is not something that we simply do and something that also 'does' us, it is the conceptualisation of the term in multiplicity that undoes the dualistic form of thinking that locates it in binary or classificatory forms.

It seems that the interiority that is implicit in your challenge to what I see as the 'hylomorphic' tendencies that manifest in the more obviously prescriptive form of 'writing to 
it' also opens us up to enactments of affect. Simondon points out and Deleuze and Guattari (1987: 268) apply the concept of hylomorphism to describe ways in which external systems are applied to conditions of supposed chaos and/or passivity; it sets in place the attack on the body-without-organs. There is a politics involved in the organisational proclivities of hylomorphism which acts, through processes of territorialisation, to impose certain procedures and practices which attempt to control what might be seen as the disorganisation of the body-without-organs. Deleuze and Guattari see these hylomorphic tendencies as being agentic in the way that they act upon and within organisational assemblages to limit experimentation and to promote representation and identification. Examples of this can be found working in relation to regimes of signification as in the use of particular codes, tropes and linguistic conventions. Bennett's (2010) notion of 'agentic assemblages' also evokes the impositional affective productions of hylomorphism that activate limitations upon the bodywithout-organs. In this respect and echoing Spinoza, Massumi points out that, "One always affects and is affected in encounters; which is to say, through events" (2015, p. ix). Therefore, I would argue, it makes qualitatively better sense to think of these hylomorphic affects, a la Barad, and to use the neologism 'intra-vention' as a means of troubling the phenomenological and humanistically inclined proclivities of the signifier 'intervention'. The inference of Barad's use of 'intra-action' here is obvious. In talking about the means by which we can move to understand agency as being distributed through and across human and non human participants, Barad argues that:

\section{$\mathrm{J}$ : "Crucially, agency is a matter of intra-acting; it is an enactment, not something that} someone or something has. It cannot be designated as an attribute of subjects or objects (as they do not preexist as such). It is not an attribute whatsoever. Agency is 'doing' or 'being' in its intra-activity. It is the enactment of iterative changes to particular practices ... through the dynamics of intra-activity." (2007, p. 178, italics in the original) 
$\mathrm{K}$ : By engaging with Whitehead's use of process to trouble pre-eminent concerns with substance I sense that we find ourselves engaging with the practice of 'writing to it' in affect. The rhythmic transversalities that are at the processual heart of working with Spinoza's view of affect as the capacity of all bodies to affect and be affected suggests an openness and active engagement in, to and with the world. Massumi argues that this process "is the cutting edge of change. It is through it that things-in-the-making cut their transformational teeth." (2015, p. ix).

$\mathrm{J}$ : A way of coming to understand writing not as something we 'do' but as something that 'does' us. A practice we have found ourselves doing. An immanent imperative. ... Writing takes it out of us; and takes us out of ourselves; and out of it. We get out of it by writing. We have to.

$\mathrm{K}$ : You refer to writing that takes us over and, in affect, I want to talk about writing taking over. This seems to be the 'immanent imperative', the practice we have found ourselves doing. It is at this point that I sense writing in terms of becoming. Perhaps more than any other methodological phrase that we have uttered and practised is Laurel Richardson's insistence that 'writing is a method of inquiry' (Richardson \& St. Pierre, 2005). In ontological terms I sense that we are doing different things with this now than what Laurel intended when she first employed a rhetorical logic to propose this methodology all those years ago, and that's OK. The 'immanent imperative' to which you refer embraces human and non human potentialities; its agentic force is to be found in a coming to terms with the intricate knots and entanglements of materiality and discourse and, therefore, it seems to me that in these movements away from interpretation and representation 'writing to it' animates a becoming that is, in constantly processual ways, essential in its affective world making. 
You know that in our writing I have found it exciting and ultimately hugely necessary to engage with the creative nature of Deleuzian philosophical inquiry which is brought to life in the following quotation:

$\mathrm{J}$ : 'Concepts are not waiting for us ready-made, like heavenly bodies. There is no heaven for concepts. They must be invented, fabricated, or rather, created, and would be nothing without the creator's signature' (Deleuze and Guattari, 1994: 5).

$\mathrm{K}$ : What is so apposite about this statement in relation to our advocacy of the practice of 'writing to it' is that in living with and through affect this processual practice helps to bring concepts to life. 'Writing to it' is not only part of the creation of concepts it is also about doing something with them, making them work. Deleuze and Guattari propose:

$\mathrm{J}$ : 'When one writes, the only question is which other machine the literary machine can be plugged into, must be plugged into in order to work' (Deleuze and Guattari, 1987: 4).

$\mathrm{K}$ : This is not an easy or straightforward process; as Mazzei and Jackson describe in terms of their own collaborative writing processes,

$\mathrm{J}$ : "[W]e had a sense of the ceaseless variations possible in having co-authored texts that relied on a plugging in of ideas, fragments, theory, selves, sensations ... Plugging in to make something new is a constant, continuous process of making and unmaking $\ldots$ it is the process of arranging, organising, fitting together." $(2012$, p. 1)

$\mathrm{K}$ : I would suggest that the way in which they describe the process of writing as a form of 'plugging in' also through the practice of 'writing to it' involves an active territorialisation of time and space. So, for example, in engaging with what they refer to as 'minor literatures' Deleuze and Guattari (1986) also talk about 'stuttering' in the language, not to make 
reference to some form of impediment of speech or pronunciation, rather to describe, as I've written elsewhere:

$\mathrm{J}$ : "a way of speaking and writing in the language that is always emergent, hesitant, and taking new forms ... offering a 'minor literature' to de-centre and deterritorialize the dominance of 'major literatures' through strategies of experimentation, mistrust of traditional idioms and forms and of nurturing collective action.” (Author 2, 2015, p. 4)

K: I understand Deleuze and Guattari's use of the concept of 'minor literature' as having something to do with the invocation to 'write to it'. 'Writing to it' is an act; it is about bringing concepts to life, it is about writing within the molar forms of 'major literatures' and the hylomorphic tendencies of dominant and dominating structures and forms to produce difference and in producing difference territorialisation occurs. In such contexts the rhythms that are constitutive of the power to affect and be affected are, as Foucault points out, also infused with institutional forces that work to produce identification with and subjectification to representational modalities of the self. I am with Deleuze when he argues that the smallest unit is the assemblage and so I sense strongly that 'writing to it' will be writing in affective ways that engage with human and non human agency. The molar forms that 'major literatures' produce can be de-territorialised through writing to and with the heterogeneities and contingencies of molecular particularity that live with them. 'Writing to it', in bringing new concepts to life, is agentic; it animates and hence disturbs the distribution of agency and has the potential to bring new vitalities in to play in active processes of world-making.

\section{Clouding}

$\mathrm{K}$ : Writing to it is an act; it is about bringing concepts to life 
$\mathrm{J}$ : We are on the same flight together, you and I, maybe three or four hours into our trip to Illinois for the International Congress of Qualitative Inquiry. Our $12^{\text {th }}$ year. Our $12^{\text {th }}$ such journey. You are a few rows back from me in the middle section. I am at the front of the second-class section. We are both in cattle class, the section of the plane that British Airways euphemises as 'World Traveller'. I'm at the front, where the legroom is more generous, to the right, in the middle seat. (Deleuze would be happy - I'm writing in a middle to you in a middle; and we are in the middle of our flight; and our travel companions are scattered around the plane, so we could say we are in the middle of them or they of us. I'm beginning to write to you in a plethora of middles. Topographic, temporal, geographic.)

I have just re-read your latest writing. It's been in my bag for a couple of weeks since you sent it and I first read it. I am writing to it, unsure - as ever - of where it will take us; not so much a recoiling, because a recoil takes us back whence we came, and away, in a line; and usually in horror. No, not a recoil, more of a spin. In fact, we might want to re-think the phrase 'writing to it' altogether because 'writing to it' hints at direction and goal, and this is what I'm going to work at here.

Do you speak to your neighbours on these flights? I don't. Except when it's you, which we've not managed to arrange this year. I avoid contact at all costs if my neighbours are strangers to me. I like to retreat. I'll pass drinks and empties across, or say excuse me if I need to get past, but I don't want to engage in conversation. I'm not interested in them. After 8 hours of enforced, cramped proximity we will never meet again so I don't feel invested in them at all. I like to see what they're doing though. I like to observe. Ethically, of course. I don't wish to intrude on their privacy, no no.

The man to my left, whom I haven't yet spoken at all to, has started watching the most recent Star Wars film on his tiny black-edged screen. (What a sacrilege it is to watch a film on a 
screen that size, especially when you have to ram your head back against the seat to gain the distance needed from the screen. And then there's the sound quality. Don't get me started on the sound quality. How you have to turn it down when there's the soundtrack and then up again when characters are speaking.) Anyhow, I've seen this Star Wars film - it's ok, not the best, and I'm not a big fan in general - and I'm glancing over and I see the main character, Rey. She is a scavenger by trade, and we quickly gather she is very competent and experienced despite her youth. When we first meet her, she is plundering whatever booty she can find. She loads it onto her craft, which is some kind of very cool, if scruffy, hover machine - a kind of floating dilapidated motorbike - and - just at the moment of writing this sentence - she is heading back to her home village, if that's what it can be called. She is purposeful. She has direction. She is travelling from wilderness to her home. From, to. She is 'recoiling' herself back home, such as it is.

So I'm not writing 'to' your writing in Rey's sense. I'm not heading from your writing back to somewhere else I know.

$\mathrm{K}$ : Writing to it is an act; it is about bringing concepts to life.

$\mathrm{J}$ : Of course, what happens next takes Rey on a complicated and dangerous journey a long way from home - on a feisty, incident-packed line of flight - so maybe this Star Wars plot line stands as a better metaphor for 'writing to it' than I'm suggesting.

Maybe, though, we can find a different concept to 'writing to it', one that more readily speaks to how we're thinking of writing not as linear, not as going back and forth from one place to another, but in the sense of the 'immanent imperative' that seeks, as you suggest, to produce difference, engages with human and non human agency, and is agentic in itself. A writing that takes over. 
$\mathrm{K}$ : Writing to it is an act; it is about bringing concepts to life.

$\mathrm{J}$ : I keep needing to repeat this phrase of yours in order to help us in this theorising-inpractice of writing. To help both create and bring concepts to life in the becomings of posthuman education research (Gough and Gough, 2016).

To my other side - I'm in the middle, as I say - my neighbour (a young American woman, is all I know) is asleep. I look out of the window in front of us and see the contours of the wing and a vast, Rolls-Royce engine; through the window just behind I see the level ridges of cloud that themselves must be travelling fast, taking their own lines of flight on and with the wind and weather patterns shaping and moving them.

Which sets me wondering:

Maybe we can think of 'writing to it' in terms of the agency of weather. Writing as clouding, as a process of gathering and moving and dispersing and travelling, and doing so in response to and "intra-acting" with the winds, currents and forces with/in/into which clouds are embrangled. 'Writing to it' as clouding is a way too of suggesting what it does to us as we write: how 'writing to it' does not necessarily clarify but leads us into darkness, into a fog of uncertainty, blurring our senses. It is an 'immanent imperative' that may get us lost, that troubles, that messes up. Clouding as writing take us into what we don't know. In this respect we can think of 'clouding' not as a form of control, as suggested by Sellers and Gough's (2008) practice of 'cloud-sculpting', rather as processes of experimentation, where unforeseen encounters and events might come about.

Clouding as writing may have different powers than we imagine. Like Helen Macdonald's hawk writing might enable us to 
$\mathrm{K}:$ “... see colours [we] cannot, right into the ultraviolet spectrum. [It might] see polarised light, too, watch thermals of warm air rise, roil, and spill into clouds, and trace, too, the magnetic lines of force that stretch across the earth.” (2014, p. 98)

$\mathrm{J}$ : Clouding suggest a process of writing that holds substance - moisture - but only in passing. No, that's not right: clouding is a writing that does not hold but becomes substance, becomes other: making and undoing; making and undoing; and always becoming.

Clouds can give the appearance of uniformity and stability from this height as they stretch into the distance but they are always forming and re-forming. They can appear beautiful and welcoming but we have to be wary. They - like the concepts we play with and create - will not hold all we wish them to. When we are clouding, when the writing/clouding takes us over, the ride can be bumpy.

$\mathrm{K}$ : Writing to it is an act; it is about bringing concepts to life

$\mathrm{J}$ : ...even if those concepts don't serve us well or for long. I don't want to make great claims for clouding, given my evident meteorological deficiencies. But see where it takes you, takes us.

Meanwhile, I'll stop writing - stop clouding - and join one of my neighbours, either in watching something or in closing my eyes. Either way, I'm hoping I'll seem immersed enough for neither of them to try talking to me, though they have seemed as uninterested in me as I am in them.

\section{Clouding (2): Ken's response}


$\mathrm{K}$ : I am with you in your flight above the clouds and with you as you consider 'clouding' as part of our creative practice of producing concepts as events. In (y)our flight I am drawn to my seemingly eternally unavoidable return to the Art Institute in Chicago and the pilgrimage I have made now for twelve years to stand in wonder and gaze up at Georgia O' Keefe's epic painting Sky above Clouds, her immense production of infinite skyspace which always takes me on new and different lines of fantasy making and sensing the world differently.

On a canvas that measures an awesome 24 foot by $8 \mathrm{ft}$ and which she painted when she was 77 years old innumerable clouds silently drift into an always receding horizon; the meeting of the clouds and the horizon is indistinct yet luminescent and the title, Sky above Clouds, suggests the possibilities of endlessness. This painting always takes my breath away and leads me to interfere with the ways in which I write; it is as if the clouds are floating off, out, toward and beyond the horizon and I sense a writerly self that wants to engage in the same kinds of journeying. The knowing that infinity is always just around the corner is a huge motivation to start in the middle and write and write again. And so the practice we have called 'writing to it', in multiplicity, energises those becomings that are always new, encouraging an affective working through the intensities that are always changing and that give us life.

And yes, as I engage with your writing, there is a sense in which recoil can be understood as a reeling back, perhaps, as you suggest, in horror, as something that acts in readiness of another round, a reloading, a retort, a rewinding coiling up process that enables another spring. The annual repetition of engaging with Georgia O'Keefe's painting, of entering the grand coolness of the gallery, of walking up the stairs from the ground floor, of craning my neck and straining my head back to take in the enormity of this powerful image is always different. I sit and absorb, I take pictures and fill my journal with notes and then move on: I 
coil in and around the intensities that are emergent in the affective immensity of this space; my re-coiling is one of difference, something new is always undone.

$\mathrm{J}$ : Clouding is a writing that does not hold but becomes substance, becomes other: making and undoing; making and undoing; and always becoming.

$\mathrm{K}$ : Here I sense rhythm and I reel out my emergent understanding of Deleuze's notion of the refrain which Alecia Jackson describes as

$\mathrm{J}$ : "repetitious and rhythmic patterns of sound and movement that stake out a territory (that) have a catalytic function to make something new, such as when music takes hold of a refrain and releases into an improvisational creative expression.” (Jackson, 2016, p. 1)

K: So it seems to me that engaging in the practice of 'writing to it' we are animating ontological selves and actively producing, through the animation of a philosophy of the event, what Deleuze and Guattari refer to as 'minor literatures'. There is a sense in which the 'it' in this phrase might be seen as signifying some 'thing', some kind of object that is categorised in difference. That is how I could describe my writing in and around the intensities I sense in relation to O'Keefe's painting: that is not the intention here.

I understand 'writing to it' as involving a writing to, a writing with, a writing to inquire into what might be troubling, what might be emerging in conversation, bringing about laughter, generating pain: 'writing to it' is affective and it is creative in engaging with the constant processual entanglings of materiality and discourse that are involved in bringing concepts to life. The notion of writing to a determinate object is not our intent; indeed in 'writing to it' the determinacy of objects becomes deeply troubled, seriously fractured and ultimately eliminated. So I feel really comfortable with the notion of 'writing as clouding' that you have offered in your last piece of writing, it takes me to the differences in repetition involved in 
immersions of self in Georgia O'Keeffe's painting and it encourages me to engage in, as you say,

$\mathrm{J}$ : "a process of gathering and moving and dispersing and travelling, and doing so in response to and "intra-acting" with the winds, currents and forces with/in/into which clouds are embrangled."

$\mathrm{K}$ : When you describe 'clouding as writing' in terms of

J: "[the]'immanent imperative' that may get us lost, that troubles, that messes up ... (that) take(s) us into what we don't know"

$\mathrm{K}$ : I gain a powerful sense of writing as affect. The immanence of writing (to it) brings us in line with Spinoza's oft quoted and highly rhetorical question, 'What can a body do?' Writing is not simply a practice, a task, an activity that bodies do from time to time and in certain places; in these terms, writing is an affective condition of selves in relationality. As you say, $\mathrm{J}$ : "Clouding is a way ... of suggesting what it does to us as we write."

$\mathrm{K}$ : I see that in our work, 'writing to it' is about desire; it is about always producing new concepts as a means of both dealing with and creating the world: as you say,

J: it "does not necessarily clarify but leads us into darkness, into ... fog(s) of uncertainty, blurring our senses"

$\mathrm{K}: \ldots$ and in this it is about world making. Therefore, writing to produce concepts that are always new is the animation of the practice of the encounter. Each new concept that 'writing to it' produces is an event that sets up an encounter with the world: writing does. In making these claims it seems imperative that we draw down Austin's work on performative utterances and work with his view that 'speech acts' and argue that writing acts: writing does, 
it is performative, in the sense that Della Pollock claims, "[recognising] its delays and displacements while proceeding as writing toward engaged, embodied, material ends." (Pollock, 1998, p. 96). In making these claims we can make a move away from representational domains of signification and identification and, in so doing, trouble the concerns of the academy that bind pedagogy and inquiry within the entanglements of interpretation, analysis and criticality.

\section{$\mathrm{J}$ : Clouding is a way ... of suggesting what it does to us as we write.}

$\mathrm{K}$ : I want to argue that writing to it is event/ful, it is instigative of generating becomings in worlds of multiplicity, it is about event/uality and involves, in Whitehead's terms, always engaging with process prior to substance: in these respects it is a creative act, it is a writing into the not yet known. I sense that, with time, space is made; I sense its relationality and its potency in terms of movement in moments. I am motivated by Thrift in his promotion of a 'processual sensualism' and wish to employ this in precedence to and in preference of an Enlightenment logic of reason and rationality. In 'writing to it' I sense that we are using what Deleuze referred to as a 'logic of sense' to think with and through affect. It is important to assert that we are not using writing to reflect, to somehow attempt to engage in a mirroring of reality, in collaboratively 'writing to it' we are engaged in concept forming and, with Haraway (1994) and Barad (2007), using writing as a diffractive practice which does not simply reflectively engage with the world but interferes with it, troubles it and, in so doing, makes it different.

\section{J: Clouding is a writing that does not hold but becomes substance, becomes other: making} and undoing; making and undoing; and always becoming.

K: So 'writing to it' has a political valency: in saying that writing does, it feels to me that we are also saying that writing does in particularity, in different ways. I make sense of what we 
do when 'writing to it' in terms of what Deleuze and Guattari (1986) refer to as 'minor literatures'. These literatures stutter in the language to create new languages that trouble and disrupt the discursive orthodoxies and traditionalised tropic tendencies of the "major literatures' that it works within. In this we can animate 'writing to it' as a politics of the event and be constantly attentive to Spinoza's claim to which, in my theorising as practice, I find myself returning again and again, that all bodies, human and non human, have the capacity to affect and be affected.

Again, and also in Spinoza's terms, writing as an engagement with affect is to do with power. As we write collaboratively we are with Deleuze and Guattari when they argue that the smallest unit is the assemblage. In this respect we can work to further animate the shift away from the humanist and Cartesian concerns with the individual; writing is not about individualisation, it is about constant processes of becoming in relationality, of individuation. In this respect I understand and want to use the concept of the assemblage in its original form of agencement and, in so doing, take cognisance of Bennett's claim that all assemblages are agentic, in heterogeneity and contingency; they do something, they act. The capacity to affect and be affected is a capacity of all things and, as Bennett argues, the vibrancy of matter can be understood in terms of 'thing power'. The vibrancy and vitality of matter is entangled with the writing that is imbricated within it; in these entanglements, writing and materiality coexist in the affective complexities of intra-action, where place can never be pinned down and located and where space is the constant animation of what Massumi describes as an 'invitation to voyage' -

\section{J: [in] a process of gathering and moving and dispersing and travelling... intra-acting with} the winds, currents and forces ... [perhaps leading us] into darkness, into a fog of uncertainty, blurring our senses...[that] get[s] us lost, that troubles, that messes up. Clouding as writing takes us into what we don't know. 
$\mathrm{K}$ : 'Writing to it' is a cartographic practice; it is a mapping that is cognitively attuned and sensitively oriented to worlds in the making, to active processes of world making. The processual nature of affecting and being affected creates space (not takes place) in and through events; it involves writing as doing, as encounter. 'Writing to it' works to dissolve those binaries of difference that categorise subject and object, nature and culture, theory and practice by positing transitive modalities of 'what if': What if I plug this little piece of writing into this space? What if I theorise this practice this way instead of that? What if, here and now on these pages, we were to write otherwise, disrupting the ' $\mathrm{K}$ ' and ' $\mathrm{J}$ ' that are suggestive of the binaries we're writing against? And so on. And, again, as Massumi says,

$\mathrm{J}$ : "affect is only understood as enacted" (ref)

$\mathrm{K}: \ldots$ and, therefore, writing through and with affect is a cartographic tendency which activates constant attention to what a body, our bodies, any body can do.

\section{Another recoil(ing)}

J: Yes, my friend, yes to all of that: 'Writing to it' as event/ful, affect/ful, power/ful; writing to it that does; writing as encounter; writing that makes possible. A way of becoming with writing which this paper is proposing, offering, inviting.

The 'where' I am in and of now, this mo(ve)ment, is changing as I write. As we move towards the end of creating this paper I am going to experiment. (And I am going to re-claim 'experiment' as an act of unfolding immanence, not of controlled fixity.) I am going to write without writing about what surrounds me, what is happening nearby, by me, what I can hear, touch, see, pick up, sense, what is being suggested in, by and through what I might loosely call 'my' body. Unlike before. I am not going to write about someone sitting next to me on a 
train. I am not going to bring my neighbours on a flight onto our page. I will resist. I will try to allow 'writing to it', allow clouding, to work differently. Situating yourself, bringing place and space, writing on/with the body, is not something you have done explicitly in your writing this time, though sometimes you do. I am addicted to it, I think. I wonder how our writing habits, our writing familiars, our tics, perhaps limit? Maybe my tendency to think with what is around me is because the rhythm of travel seems to draw me to locate myself, even if only for a moment.

This is my 'writing to it' today, to allow what might at times striate take us into smooth space. Perhaps.

This will be different. It is difficult to not tell you of the heartfelt conversation right by me. A baby boy's cry. The sun on my skin. Being alone and away from home. As you can see, this is difficult. I am trying to start from somewhere else.

But perhaps not so different. These are all present in the act and the affect of this writing now. They can't not be. As yours are present too, however and wherever you write. In your notebook at the pub in Kingsand, standing outside with your pint of Betty Stogs on the convenient wooden shelf, looking out over the settling sea. Or in your study, upstairs at home, the room at the back with the steep steps up to it, the room that catches the evening sun. You will have been writing in places such as these. Writing to it. Catching the affect in the tips of your fingers, as it spreads across the screen, your body changing as you write; your body affected by how the words shape themselves.

In turn, wherever I am - on the train, on a plane, in my office at work, where I have to trek up flights of stairs to the printer, key in a code, and wait, then head downstairs to the School office to find a stapler, before the pages are in my hand, ready to read - there, as I read, your words - you - affect me. I write to it. The clouding begins. And begins. And begins. 


\section{References}

Barad, K. (2007) Meeting the universe halfway: quantum physics and the entanglement of matter and meaning Durham and London: Duke University Press.

Bennett, J (2010) Vibrant matter: the political ecology of things London: Duke University Press.

Deleuze, G. and Guattari, F. (1986) Kafka: Toward a minor literature Translated by Dana Polan Minneapolis: University of Minnesota Press

Deleuze, G. and Guattari, F. (1987) A thousand plateaus: capitalism and schizophrenia Translated by Brian Massumi, London: Athlone Press.

Deleuze, G. and Guattari, F. (1994) What is philosophy Translated by Hugh Tomlinson and Graham Burchill, London: Verso.

Author 2 (2015)

Author 2 \& Author 1 (2009).

Deleuze, G. and Parnet, C. (2002) Dialogues II Translated by Hugh Tomlinson and Barbara Habberjam, London: Continuum.

Gough, A. and Gough, N. (2016). Beyond cyborg subjectivities: Becoming-posthumanist educational researchers, Educational Philosophy and Theory, DOI: 10.1080/00131857.2016.1174099

Guttorm, H E, Hilton, K, Jonsdottir, G U, Löytönen, T, McKenzie, L, Gale, K, and Wyatt, J (2012) Encountering Deleuze: Collaborative writing and the politics of stuttering in emergent language. International Review of Qualitative Research, 5, 4, 377-398

Haraway, D. (1994) A game of cat's cradle: Science studies, feminist theory, cultural studies Configurations: A Journal of Literature, Science and Technology, 2(1), 59-71.

Heron, J (2001) Helping the client: a creative practical guide. London: Sage.

Lee, K. V. (2005). Neuroticism: end of a doctoral dissertation. Qualitative Inquiry, 11(6), 933-938.

Massumi, B. (2015) The politics of affect Cambridge: Polity Press.

Mazzei, L and Jackson, A. (2012) Thinking with theory in qualitative research London: Routledge.

Macdonald, H. (2014). H is for Hawk. London: Jonathan Cape.

Pollock, D. (1998). Performing writing. In P. Phelan \& J. Lane (Eds.), The ends of performance (pp. 73-103). London: New York University Press.

Richardson, L. and St. Pierre, (2005) Writing: A method of inquiry in Denzin, N. and Lincoln, Y. (Eds.) The Sage Handbook of Qualitative Research $3^{\text {rd }}$ edition Thousand Oaks, CA: Sage. 
Sellers, W. and Gough, N. (2008) Currere and cloud-sculpting, In J Knowles, S. Promislow and A. Cole (Eds.) Creating scholartistry: Imaging the arts-informed thesis or dissertation, pp. 223-233. Halifax, Nova Scotia: Backalong Books.

Sellers, W. and Gough, N. (2010) Sharing outsider thinking: thinking (differently) with Deleuze in educational philosophy and curriculum inquiry. International Journal of Qualitative Studies in Education 23(5): 589-614.

This is an Accepted Manuscript of an article published by Taylor \& Francis in International Journal of Qualitative Studies in Education on [17 Jul 2017], available online: http://www-tandfonline-

com.plymouth.idm.oclc.org/doi/full/10.1080/09518398.2017.1349957 